\title{
EATING THE LOUSE AND ITS LARVA! THE INDIGNITY OF POVERTY AS EMBEDDED WITHIN SELECTED AFRICAN AND OLD TESTAMENT PROVERBS
}

\author{
Madipoane Masenya (ngwan'a Mphahlele) \\ Department of Biblical and Ancient Studies \\ University of South Africa
}

\begin{abstract}
Go hloka le pudi ya leleme le letala, ie, to lack even a green-tongued goat, is an African idiom which reveals extreme poverty for one who lacks such a goat. Such a person "eats a louse and uses its larva as relish!" From the wisdom literature of African peoples, it becomes evident that even in pre-colonial Africa, poverty stared some in the eye. Similarly, some Old Testament scholars argue for a popular setting of the Book of Proverbs. Using the Marikana incident as a hermeneutical lens to show the indignity of poverty, I argue in this article that to be poor, is to be deprived of human dignity. Selected Northern Sotho/Pedi and Old Testament proverbs will also be used to show the indignity of living in poverty.
\end{abstract}

Key Words: Book of Proverbs, Northern Sotho/Pedi proverbs, Poverty, Marikana Mineworkers and Human Dignity

The Marikana Massacre was undoubtedly a turning point in our history. If we fail to act decisively we do so at our peril. If as a young democracy we are to emerge stronger and better we need the truth and we need to spare nobody's position or reputation. Above all we need a new deal for our mine workers and we need a system based on economic justice for the poor of our land (Kasrils 2012:16).

\section{Introduction}

Mo go hwilego bomoloto talane ntshe e sa topiwa, at a place where a rich person had slept, the poor will flock to, to pick on the crumbs that might have fallen (Rakoma 1970:170). Also, motse re reta wa balata, wa babinakgomo ra tsena (Rakoma 1970:188), nobody visits the households of the poor; however, those of the rich always have visitors as the visitors know that they will have plenty to eat and rejoice. According to the sage, the possessions of an individual are only a means of gaining friends (Prov 19:7b). Perhaps they were inspired by the preceding proverbs. Some of them were/are migrant labourers. Having heeded the proverb, se se hwago se a ithagathagela, that which is dying, wrestles with its plight (Rakoma 1970:217), they refused to be overwhelmed by poverty. In a bid to drive hunger from their households, they ended up toiling in the Lonmin platinum mine in the Northwest province of South Africa. It is a well-known fact that South Africa is one of the most economically unequal countries in the world.

Kota has captured this dire situation succinctly: 
South Africa is the most unequal country in the world. The amount of poverty is excessive. In every township there are shacks with no sanitation and electricity. Unemployment is hovering around $40 \%$. Economic inequality is matched with political inequality. Everywhere activists are facing serious repression from the police and from local party structures. Mining has been central to the history of repression in South Africa. Mining made Sandton to be Sandton and the bantustans of the Eastern Cape to be the desolate places that they still are. Mining in South Africa also made the elites in England rich by exploiting workers in South Africa. You cannot understand why the rural Eastern Cape is poor without understanding why Sandton and the City of London are rich (Kota 2012:5).

Some of the miners are stuck in the perpetual cycle of poverty which was inherited from the inequities of the apartheid era. Thus, for them, having ended up working under appalling inhuman conditions which typify many a South African mine, was the only option, perhaps the best option given the high unemployment rate in the country. ${ }^{1}$ The African ancestor was right when he lamented that moroto wa tšhego, o elela le leoto, the urine of scarcity flows along the (female) leg in his/her attempt to portray the harsh reality of perpetual poverty. Perhaps some of them ended up in such situations due to their own making after having abused opportunities offered by parents to obtain an education. These are the Marikana mine workers.

Poor as they are, the workers produce immense wealth for the fortunate few. Indeed, the sage was right that "The rich rule over the poor ( $r \bar{a}$ šîm), and the borrower is the slave of the lender" (Prov 22:7) ${ }^{2}$. Destitute as they are, they work in one of the leading platinum producing mines in the world. Their lives? A shameful contrast! ${ }^{3}$ Indeed, "the field of the poor ('rashim) may yield much food, but it is swept away through injustice" (Prov 13:23).

Rodrigues call the workers, "the professors of their own suffering". He continues:

Refer to a staggering figure such as 3,2 million of unemployed youth, many of whom are certificated!

2 The few references to 'ebyon and 'ani are overshadowed by the frequent use of dal, sar and mahsor in the book of Proverbs. Also, Proverbs 1-22 does not connect the term 'ani to the socio-economic oppression of the poor by the ruling elite. Plein reasons that the fact that sages in Proverbs, use the words, dal, ras and mahsor, in the context of poverty (such a usage is missing in prophetic literature), reveals the significant difference in the value systems of the prophets and sages (1987:63, 65-66). According to Kuschke (1939:45), in the wisdom literature, the use of rus, hsr and misken is made when poverty is subjected to scorn. However, the words 'byon, dal and 'ani are employed when based on religious grounds, an inner sympathy is expressed for the fate of the poor, and a call made for relevant action to address the dire situation. According to Wittenberg though: "The contrasting usage of the poor (negative value) and 'rich' (positive value) is restricted almost entirely to the term raš and 'ašir." The only other term used in opposition to 'ašir (wealth/rich) is dal. 'ebyon is not used at all. 'ani, likewise is never used as an opposite of 'ašir. With reference to the general situation of poverty, it occurs only once in a borderline case in 15:15 Exceptions to the general pattern are 28:11 and 29:13. In 28:11 the view of poverty is no longer totally negative, while wealth connected with pride, loses its positive value. The term used for poor is dal" (1986:48-49).

3 On the glaring inequalities of our country, we do not need to go too far to glimpse the inequities entrenched by the ruling power itself. Kota (2012:6) contends: "The ANC has killed workers for demanding a salary increment from a notoriously exploitative and very, very rich company. The workers earn only R4000 per month doing the most dangerous work. The ANC president and cabinet minters earn not less than R2 million per year. And on top of that there is corruption everywhere. Our politicians are part of the global elite. The lowest ANC employee earns not less than R20 000 excluding benefits. The Marikana mine workers lived in shacks with their families. The president of the ANC has recently built a mansion in his homestead, a mansion that cost tax payers not less than R200 million. It is the ANC government that shoots and kills protesters when they are fighting for the assertion of their humanity. They recently killed Andries Tatane. They have killed at least 25 others on protests since 2000. If you are poor and black your life counts for nothing to the ANC" (Kota 2012:6). 
They can draft PhD's on the political economy of death. They can riff better than any broker about the price of platinum. They can wax like lawyers about police statements. But what still embitters them is their understanding that they would have to be reincarnated many times over to earn what the CEO of Lonmin did in one single year. Comparing their salary of R48000 per annum with Ian Farmer's (2011) earnings of R20 358620 amounts to an approximately 424 years discrepancy. Taking a recent estimate of average male life expectancy in South Africa (49.81) and deducting just 18 childhood years from that would mean even if they worked every day of their adult lifethey would have to do so over 13 unlucky lifetimes! Such is the normalization of this capitalist metaphysics that the rival union has been universally rebuked for wanting to reduce it to a ratio of 1 year:4:26 life spans. No wonder these strikers then entrusted the magic realism of a sangoma, for nothing today needs to be more urgently remedied than 'reality' (Rodrigues 2012:8).

The workers understand the tenor of the proverb, marekhu a a išwe meokeng, that no coal needs to go to Newcastle. From the African proverbial lore, they know that the haves have a responsibility to share with the poor (Rakoma 1970:161). ${ }^{4}$ This is no charity though, as in the interest of honouring human dignity, each human being must receive a fair wage for the work of his/her hands. In that sense, the mine workers challenged the notion that a beggar must just receive whatever he/she gets! Sa mpša ke seo se tsogago (Rakoma 1970:212). The Marikana workers also know that only those who complain can be assisted through their troubles as senamolomo se na le malome wa sona ${ }^{5}$ (1970:216).

Most of these workers dwell in one-roomed zinc shacks in the neighbourhood of the platinum mine. They work under dangerous conditions. Kota remarks:

The Marikana Mine is the richest platinum mine in the world: yet its workers live in shacks. Most of the slain workers are rock drillers, the most difficult and dangerous work in the mine. They do the most dangerous work in the mine and yet they only earn R4 000 a month. Through the blood and sweat in the mines they do not only produce wealth that is alienated from them, they also produce the fat cats, which wine and dine on naked bodies and call that sushi (Kota 2012:5).

They understood the truth about a proverbial locust which can fly only when its stomach is full. Persuaded by the tenor of the proverb, maahlo a tlala ga a bone (hungry eyes cannot see) (Rakoma 1970:157), they decided to negotiate for a living wage (Magome 2012:1). However, their efforts fell on deaf ears. When they chose to vote with their feet, opting for the course of justice and fairness by using the only language which the exploitative employers seem to understand, that is, protest, little did they know that some of them would meet with their untimely deaths! They could not imagine that the very same one whom they had elected to be their guardian, their protector, that is, the state, would order their demise. Bishop Rubin Phillip's comments are in order:

Other proverbs conveying the understanding that the rich have a responsibility towards the poor are: monabjala ga a tsebe monammela, meaning that it is not appropriate that when one has something good, one becomes stingy, as tomorrow the poor will also get such good things. When they will reciprocate what he/she did to them, s/he will complain (Rakoma 1970:180). The proverb, noka e tlala ka melatswana has the following tenor, a human being grows through the assistance of the members of his/her family, and eventually become a prominent wealthy person (Rakoma 1970:198).

5 Literally, "that which has a mouth, has its own uncle". In the Northern Sotho/Pedi context, one's uncle performs an important function particularly where negotiations have to be made. 
And so, again, the truth of our country is in dead black bodies littering the ground. Once again the truth of our time is that people asserting their rights and dignity against systemic injustice have been brought down in a hail of bullets. Has nothing changed in our place, ${ }^{6}$ when its truth remains that the armed might of the state acts for the elite of powerful and wealthy, and against our people? No self-righteous declarations of 'tragedy'; no insisting on 'complexity', 'commissions of enquiry'; are enough to hide that truth. The truth is plain to masses of the people of South Africa, it is an affront to God (Phillip 2012:3).

Such is the plight of those who are acquainted with the indignity of picking only the fallen crumbs of the rich, that is, ba go topa ťsa fase according to the African idiom. Such are undesirable elements of our communities, the disposables, the proverbial wet dogs without owners (mpša ga e nailwe ga e na mong). These are people who are so poor even to the embarrassment of their next-of-kin (Rakoma 1970:192). Does it then occasion any surprise that the wisdom teacher had argued, "If the poor are hated even by their kin, how much more are they shunned by their friends! When they call after them, they are not there." (Prov 19:7). Wittenberg reasons, "In this proverb, poverty as an evil and dehumanizing social condition is studied, so to speak, in isolation by simply concentrating on the effects it has on human life" (1986:51). Are the rich not being wearied by the repeated requests of the poor? Is it not it that mphe mphe e a lapiša motho o kgonwa ke sa gagwe, that is, the object of begging gets tired by the beggar's constant requests. The beggar must have his/her own! The preceding thought is endorsed by the sage when he says: The poor ( $r a \hat{s})$ man's repeated requests for help have brought on the strained relationship with his family (Prov 19:7b). Indeed, seť̌wagodimo se kgetha ngwana wa moloi (Rakoma 1970:218), persecutions/challenges come to the unfortunate of our communities, those who eat the louse and use its larva as a relish, the weak and the poor. Such is the indignity of those who sit on the margins of our communities.

In an ironic tragedy of our new democracy, 34 mineworkers were killed and approximately 80 of them wounded (Kasrils 2012:16) as they sought to regain their human dignity in their desire to earn a living wage. The workers were killed as they were fleeing from the police. The preceding is attested to by research done, the reports given and the footages seen (and those not covered by/on) television. The post mortem results also confirmed that the bullets from most bodies were shot in the backs and came through their chests (Ndaba 2012:18) ${ }^{7}$. What a tragedy! Ndebele rightly asks: "What led a movement of 100 years of struggle to misinterpret the actions of the poorest of its followers and turn them into enemies?" (2012:21). One can imagine that some of the deceased left young widows and

6 In the same vein, Greg Mills, in his analysis of the lessons from the Marakana tragedy comments: "First, that policing has improved little, if at all, from the bad old days. Not only has it been increasingly militarized, but it is permeated with a dangerous chauvinism. The likes of PW Botha at his finger-wagging best would have been envious" (2012:15).

7 In the days after the shooting, Themba visited friends at the nearby mine hospital. "Most people who are in hospital were shot at the back. The ones I saw in hospital had clear signs of being run over by the Nyalas," he said. "I never got to go to the mortuary, but most people who went there told me that they couldn't recognize the faces of the dead (they were so damaged by either bullets of from being driven over)."

"Tsepo said many people had been killed at the small koppie and it had never been covered (by the media). He agreed to take us to the small koppie, because that is where many, many people died," Mmope said.

"At that time, there were bullets coming from a helicopter above them. Tsepo then lay down. A number of fellow strikers also lay down. He says he watched Nyalas driving over the prostrate, living miners," Mmope said. "Other miners ran to the koppie, and that was where they were shot by police and the army with machine guns"(Marinovich 2012:3-4). 
orphans behind. They have died in their search for justice and human dignity. In the aftermath of the strike of the mineworkers of the Penge asbestos mine in the then Northwestern Transvaal, a strike which eventually led to the firing of all the workers, one trade unionist had this to say at a later stage: "We don't envisage a situation where we would choose to die in order to earn very little. We we'd rather starve than sell our lives" (Soske 2012:11). That was not to be the case with the Marikana fatalities though. One cannot but wonder if the exploiters of the weak, are aware that the Maker, who is the Maker of both the rich and the poor ( $r \bar{a} s$ ) (cf. Prov 22:2), pleads the course of the poor. Says the sage: "Do not rob the poor $(d a l)$ because they are poor $(d \bar{a} l)$, or crush the afflicted at the gate; for the LORD pleads their cause and despoils of life those who despoil them" (Prov 22:22-23).

After the Marikana massacre, indeed many sentiments were raised by both government and the media alike. Reports ranging from messages of sympathies to the affected families, the assurance that the families would be assisted with the funeral arrangements, anger directed at the Zuma government and its uncaring attitude. ${ }^{8}$ That the government has been ruthless towards the civilians, particularly the protesters; anger directed at NUM and its incapacity to address the needs of the mineworkers, towards Malema as an instigator; towards Zuma's apparent reluctance and incapacity to act swiftly to address the plight of the Marikana mineworkers among others.

Unfortunately, what one found seldom addressed, is what in my view, the main contributor to the plight of the mineworkers, the beneficiaries to Lonmin platinum mine itself! Indeed, they could have prevented this by refusing the inclinations of those on top, to exploit the poor. They could have given the workers a living wage. They could have seen this coming by addressing the demands of the workers as included in the memorandum which was submitted to the company already in July (Magome 2012:1). Or better still, they could have heeded the proverbial warning, "Those who oppress the poor (dâl) insult their Maker, but those who are kind to the needy honour him"(Prov 14:31). The Shambala proverb points in the same direction when it says: If you revile an ape (e.g. for having stolen your maize) you revile his Creator who appointed the manner in which he should seek food (Johanssen 1931:535). Tempies (1980:29) rightly argues, "God as the common Creator of the oppressor and the oppressed is despised or reproached when the poor person is unkindly treated by the oppressor. Those who are poor in material things or destitute (אבין), need gracious and sympathetic help. God's honour is involved in the gracious helping of the destitute".

Alas, that was not to be case. Instead, even after the Marikana tragedy, the Chief Executive Officer can, from his position of comfort, wallow in self-praise and arrogance. McMichael's comments on Lonmin Platinum are on target:

\footnotetext{
Mills argues: “...national political leadership has been absent, not just in relation to Marikana and the mines, but in terms of setting an overall direction. Leaders have failed to provide the development "story" - the Big Idea - into which South Africans can buy"(2012:15). Mamphele Ramphele's remarks are illuminating: "The ANC leadership has become more and more intolerant and less and less willing to appreciate the importance of listening to citizens as the ones to whom they are accountable. Only a radical redefinition of politics can remedy this situation. The very nature of power will have to be redefined in a paradigm that puts the citizen back at the centre of the political process - where he/she belongs. The Marikana massacre demands this redefinition. Our government has been found wanting both in anticipating the crisis and in its reaction to it. The ANC and its alliance partners, including the National Union of Mineworkers (NUM), are unable to respond to the challenge of legitimacy the workers pose to them. But neither is the rest of South Africa, including the private-sector leadership that has been coasting and playing the game of power instead of leading the transformation process in the socioeconomic sphere" (2012:5).
} 
A company so venal, that in response to the massacre it issued a self-congratulatory press noting all of its good works in the community. A company so callous that it issues ultimatums demanding that drill operators return to work regardless of what just happened and implies that as the strike was "illegal", the dead had it coming. A company much like other mining operations throughout the country, and the continent, which extract vast profits from the dangerous jobs of their wage slaves, which wreck environments and communities, which sponsor cheap 'upliftment' projects to salve executive consciences, which cower behind the shield of the state when things explode (McMichael 2012:10).

\section{Poverty and Human Indignity: An Overview of Selected African and Old Testament Proverbs}

From the preceding interaction between selected African (Northern Sotho/Pedi) and Old Testament proverbs, it has hopefully become clear that poverty, is an affront to human dignity:

- To be poor, is to be an easy candidate for theft. In Proverbs 30:8-9 we read, "Remove from me falsehood and lying; give me neither poverty ( $r \hat{e}$ 's $)$ nor riches; feed me with the food that I need or I shall be full, and deny you, and say, "Who is the LORD?" Or I shall be poor ( $r \bar{e} \check{s})$, and steal, and profane the name of my God" (Prov 30:8-9).

- To be poor, is to be repelled by friends, it is to attract hatred. The proverbial wet dog without an owner has said it all, mpša ga e nailwe ga e na mong. Its tenor reveals that people can be so poor even to the embarrassment of their next-of-kin (Rakoma 1970:192). Likewise the sage writes: "If the poor ( $r \bar{a} s)^{2}$ are hated even by their kin, how much more are they shunned by their friends. When they call after them, they are not there." (Prov 19:7). Equally, the poor man's repeated requests for help have brought him a strained relationship with his family (Prov 19:7b). It was previously noted that the households of the poor are visited by nobody (motse re reta wa balata, wa babinakgomo ra tsena) (Rakoma 1970:188). ${ }^{9}$

- To be poor, is to be confronted with the shame of begging (Prov 19:7b). It is to be $a$ dependent person (Prov 18:23). Two Northern Sotho/Pedi proverbs come to mind here: mokwatšhego, tsogela mareneng whose tenor is, a needy person needs to (early in the morning!) go from one family to another, seeking help from the wealthy (Rakoma 1970:175). Also, molomo ge o eja o roga wo mongwe which is literally translated as, "a mouth which eats, swears at the one which does not eat" (Rakoma 1970:178). On account of the dependent status of the poor, he/she acquires a subservient role to the rich (Prov 22:7; cf. Tempies 1980:33 and Plein 1987:66).

- Oppression and exploitation become the lot of the poor. "All the days of the oppressed are wretched" (Prov 15:15). "There are those whose teeth are swords, whose teeth are knives, to devour the poor ('ániyîm) from off the earth, the needy from among the mortals" (Prov 30:14).

- To be poor is to experience the indignity of being friends with hunger. Marumo a ja mabekane ga se tlala e hlaolago, when enmity sets in, it kills everybody, unlike hunger which comes to persecute only the poor (Rakoma 1970:162). The proverb, tlala ke a neka phefo ke ja non has the following tenor, "death, unlike hunger which only chooses the poor, takes the rich who would still be reveling in their riches" (Rakoma 1970:221). According to Prov 15:15, "All the days of the poor ( $\check{n} n \hat{\imath})$ are hard, but a cheerful heart has a continual feast".

9 Many seek the favour of a generous man, and every one is a friend to a man who gives gifts (Prov 19:6). 


\section{Conclusion}

One would agree with Mosala that the starting point of our engagement with (biblical) texts, in our search to impact the contexts in which we are placed, particularly the contexts of the less fortunate, is the struggle of the exploited. He says, "The social, cultural, political and economic world of the black working class and peasantry constitutes the only valid hermeneutical starting point for a black theology of liberation" (Mosala 1993:57).

The Marikana episode is challenging us to insist on using the life experiences of oppressed people as hermeneutical lenses for engaging both the secular and sacred texts. From the preceding text, it has hopefully become clear that poverty is an affront to human dignity. In our view, human beings are affirmed by God, irrespective of their socioeconomic class. God is the Maker of both of them. God has bestowed the precious gift of life on both. According to Tempies, the latter fact buttresses the equality of both the rich and the poor. He reasons: "Thus God puts no special premium on being poor since His endowment of life to all humans equalizes the dignity of human life irrespective of one's economic station in life" (Timpies 1980:31).

Ndebele relates the tale of the Rabbit who got caught by the Lion in the act of stealing in a cave. The trap laid by Lion for Rabbit was a success as Lion found Rabbit busy stealing. Enraged, Lion pounced on the thief. When Lion was about to devour Rabbit, the latter screamed about the collapsing cave. Rabbit suggested that he could rush to go get help as Lion could prop up the ceiling with his powerful limbs in a bid to save both of them. Lion, caught up in the sudden dangerous moment and also thankful that he had not recklessly eaten a source of vital and prompt wisdom, sprang up on his hind legs, propping up the roof of the cave with his front paws. Rabbit ran away forever! Lion remained in the cave, holding his dear life in his own paws as he realized dreadfully that he was getting tired. As he pondered why lions were also made to be vulnerable to fatigue, doom hung over him. As he prepared to be buried alive, he finally let go off the roof and nothing happened. His relief at being alive was momentary as it occurred to him that Rabbit fooled him (Ndebele 2007:106).

Informed by the preceding tale, the following questions are worth pondering: Which efforts do we as Bible scholars put in place towards the emancipation and empowerment of the poor? Who holds the roof of the cave of poor-identified bible interpretation in our scholarly, societal and ecclesiastical contexts? Is it reserved to very few who struggle to exert their influence in academia? A handful whose scholarship might be dubbed not that scientific as it hovers on issues pertaining to those on the margins of our communities? Do we choose to be the Rabbit and go away scot free or do we choose to hold on to the cave lest it collapses?

\section{BIBLIOGRAPHY}

Kasrils, Ronnie 2012. Marikana Massacre: Do not blame the Victims.

Kimilike, Lechion P 2002. 'Friedemann W. Golka and African Proverbs on the Poor', Zeitschrift für die alttestamentliche Wissenschaft 114. 255-261.

Kittel, R (ed.) 1984. Biblia Hebraica Stuttgartensia. Stuttgart: Deutsche Biblestiftung.

Kota, Ayanda 2012. Unemployed Peoples Movement on the Marikana Mineworkers Massacre. A Massive Escalation in the War on the poor? Available from http://abahlali.org/node/9035. Accessed on 27 August 2012. 
Kuschke, A 1939. Arm und Reich im Alten Testament mit besonderer Berucksichtigung der nachxilischen Zeit. Zeitschrift für die alttestamentliche Wissenschaft. 171-187.

Marinovich, Greg. The murder fields of Marikana. The cold murder fields of Marikana Daily Maverick. Available from http://dailymaverick.co.za/article/2012-08-30-themurder-fields-of-marikana-the-cold-murder-fields-of-marikana. Accessed on 30 August, 2012.

McMichael, Chris. Umshini Wam. Available from http://www.mahala.co.za/reality/ umshini-wam/. Accessed on 21Aug 2012

Mills, G 2012. Sunday Times, September 23: "Cudgel your brains for Big Idea”, page 15.

Mogomotsi Magome 2012. Pretoria News, Friday14, 2012.

Ndebele, Njabulo S 2012. Liberation betrayed by bloodshed, 26 August.

Ndebele, Njabulo S 2008. Fine Lines from the Box: Further Thoughts about our Country. Houghton: Umuzi.

Phillip, Rubin 2012. Marikana Massacre Memorial Service, Emmanuel Cathedral, 24 August.

Plein, J David 1987. Poverty in the Social World of the Wise. Journal for the Study of the Old Testament 37:61-78

Rakoma, JRD 1971. Marema-ka-Dika tša Sesotho sa Leboa. Pretoria: Van Schaik.

Ramphele, M 2012. "Stop Struggle Politics” Review, Sunday Times, 23 Sept, 2012.

Rodrigues, Chris, Senzeni Na? Available from htth://www.rollingstone.co.za/opinion/ item/1351-senzeni-na. Accessed on 20 August 2012.

Soske, Jon 2012. Marikana and the New Politics of Grief . Available from http://historymatters.co.za/maikana-and-the-new-politics-of-grief-by-jon-soske/. Accessed on 27 August 2012.

Tempies CF 1980. A Study of Poverty and Prosperity in the Book of Proverbs: A Thesis Presented to the faculty of the Department of Semitics and Old Testament Studies, Dallas Theological Seminary, In partial Fulfillment of the Requirements for the Degree, master of Theology.

Wittenberg, GD 1986. The Lexical Context of the Terminology for 'Poor' in the Book of Proverbs. Scriptura S (2), 40-85. 


\title{
TRENDS IN WISDOM RESEARCH:
}

\section{A PERSPECTIVE FROM THE AFRICAN CONTINENT}

\author{
Philip J Nel \\ Research Associate, Centre for Africa Studies \\ University of the Free State
}

\begin{abstract}
The article explores crucial differences and emphases between mainstream Western interpretations of Wisdom and important scholarly voices from the continent of Africa. The divergent trends are highlighted mainly in respect of the central theme of the volume, namely, human dignity and poverty. The perspective maintained in the article to avoid undue reductionism towards a singular methodological stance and to acknowledge positively 'other' spaces for interpretation is informed by the concept of model-dependent realism. In conclusion, a few considerations are tabled which could facilitate a space of dialogue and simultaneously value a sensitivity towards a post-colonial 'African' scholarly voice.
\end{abstract}

Key Words: Wisdom Research, Proverbs, Hermeneutic models, Text Appropriation

\section{Introduction}

For two reasons it is quite challenging to speak about "trends in wisdom research - an African perspective". Firstly, 'trends' in wisdom research are multifarious and do not specify an angle of approach or context. I assume that the sub-title 'an African perspective' functions implicitly as a qualifier for a focus pertaining to interpretations of wisdom of value to an African context as well as perspectives of scholars from Africa. Secondly, contemplating an 'African perspective' will always be prone to serious over-simplification (and essentialisation), and by implication it is a homogenising attempt of multi and varied voices - not to mention the inclusion or exclusion of white/black Westernized and white Africanized voices from the continent!

The imposition of these two challenges however, provides me with the liberty to select heuristically trends in wisdom research, mainly pertaining to Proverbs, to reflect critically on issues of wisdom research relevant to Africa as context and on views of those proponents claiming to present authentically a new 'African' perspective for the interpretation and value of wisdom. The overriding brief of the volume anticipates a correlation between discussions about wisdom research and aspects of human dignity and poverty. I will restrict myself predominantly to trends in wisdom research with social-cultural assumptions and contextual (moral) appropriation of wisdom pertaining to social responsibility and poverty.

The use of 'African' in this article should not be seen as an essentialising effort as though all people and voices from the continent are homogenous. The argument of Mudimbe (1988) holds true that the concept of 'Africa' as singular entity is a Western fabrication to 'other' the continent. The concept is therefore used with inverted commas where homogenisation could be implied. However, for the sake of comparison the generalisation of 'African' is maintained to foreground pertinent scholarly voices from the continent with respect to biblical interpretation without the assumption that all voices echo the same stance. 